\title{
Development of an intensified fed-batch production platform with doubled titers using N-1 perfusion seed for cell culture manufacturing
}

\author{
Jianlin Xu*, Matthew S. Rehmann, Mengmeng Xu, Shun Zheng, Charles Hill, Qin He, Michael C. Borys
} and Zheng Jian Li

\begin{abstract}
The goal of cell culture process intensification is to increase volumetric productivity, generally by increasing viable cell density (VCD), cell specific productivity or production bioreactor utilization in manufacturing. In our previous study, process intensification in fed-batch production with higher titer or shorter duration was demonstrated by increasing the inoculation seeding density (SD) from $\sim 0.6$ (Process A) to $3-6 \times 10^{6}$ cells $/ \mathrm{mL}$ (Process B) in combination with media enrichment. In this study, we further increased SD to 10-20 $\times 10^{6}$ cells $/ \mathrm{mL}$ (Process C) using perfusion N-1 seed cultures, which increased titers already at industrially relevant levels by 100\% in 10-14 day bioreactor durations for four different mAb-expressing $\mathrm{CHO}$ cell lines. Redesigned basal and feed media were critical for maintaining higher VCD and cell specific productivity during the entire production duration, while medium enrichment, feeding strategies and temperature shift optimization to accommodate high VCDs were also important. The intensified Process $C$ was successfully scaled up in 500-L bioreactors for 3 of the 4 mAbs, and quality attributes were similar to the corresponding Process A or Process B at 1000-L scale. The fed-batch process intensification strategies developed in this study could be applied for manufacturing of other mAbs using $\mathrm{CHO}$ and other host cells.
\end{abstract}

Keywords: Fed-batch platform, Process intensification, Monoclonal antibody manufacturing, Perfusion N-1, Chinese hamster ovary cells

\section{Introduction}

Monoclonal antibody $(\mathrm{mAb})$ product development has had great success with over 80 mAbs granted marketing approvals, while the commercial pipeline is robust with over $570 \mathrm{mAbs}$ in different clinical development stages (Ecker et al. 2015; Kaplon and Reichert 2019; Walsh 2018). Global annual sales of mAbs were above $\$ 115$ billion in 2018 and are predicted to rise above $\$ 300$ billion in 2025 (Lu et al. 2020). These great achievements are partially due to the higher approval success rates

\footnotetext{
*Correspondence: jianlin.xu@bms.com

Global Product Development and Supply, Bristol-Myers Squibb Company, 38 Jackson Road, Devens, MA 01434, USA
}

for mAbs than small molecule drug products (Hay et al. 2014; Kaplon and Reichert 2019). Although great progress has been made in mAb process development, the manufacturing cost remains much higher for mAbs than small molecules. In order to reach more patients, reduce supply shortages and compete with biosimilars, reducing $\mathrm{mAb}$ manufacturing costs (e.g. by increasing cell culture titer, while maintaining desired quality) remains a major challenge (Du et al. 2019; Kunert and Reinhart 2016; Xu et al. 2018).

Current fed-batch mAb manufacturing platforms are durable and robust and have not yet fully matured (Bielser et al. 2018; Croughan et al. 2015; Kelley et al. 2018; Yongky et al. 2019). From the 1980s to the 2010s, 
manufacturing titers improved from tens of $\mathrm{mg} / \mathrm{L}$ to $\geq 3 \mathrm{~g} / \mathrm{L}$ by cell line engineering (Lin et al. 2019; Wurm 2013), media development (Galbraith et al. 2018; Huang et al. 2010; Xu et al. 2018), and process control improvements (Tang et al. 2020; Xu et al. 2019; Yoon et al. 2003) achieving higher cell specific productivities, increased peak VCDs, and prolonged high productivity durations (Kunert and Reinhart 2016; Li et al. 2010; Rader and Langer 2015; Wurm 2004). Higher titers continue to be reported in recent literature (e.g. 9-10 g/L titer in 14-18 days) (Handlogten et al. 2018; Huang et al. 2010; Takagi et al. 2017), suggesting that potential remains for further increases in productivity and reduction in cost using fed-batch operation.

In order to continue increasing volumetric productivity, many companies are pursuing process intensification, which has been used for decades in the chemical industry with continuous operation methods to improve process yield, increase product value and reduce facility footprints (Moulijn and Stankiewicz 2017; Stankiewicz and Moulijn 2000). Three parameters to increase volumetric productivity in an intensified upstream cell culture process are increasing viable cell densities, enhancing cell specific productivity, and increasing bioreactor utilization in manufacturing (including decreasing the non-productive bioreactor turnaround phase and the less-productive cell growth phase and late production phase) (Chen et al. 2018). Continuous cell culture with perfusion (i.e., perfusion production) has been successfully applied in bioprocessing, mainly to produce cells or viruses (Gallo-Ramírez et al. 2015) and low titer or unstable proteins and enzymes as the intended products (Warikoo et al. 2012). However, perfusion production processes still make up less than $10 \%$ of all commercial mammalian cell culture processes in the industry, because of challenges in process development and process characterization, complex operation requirements with high demands on automation and modeling, and the design of most manufacturing facilities for fed-batch operation (Bielser et al. 2018; Croughan et al. 2015; Kelley et al. 2018; Yongky et al. 2019).

The concept of process intensification for fed-batch cell culture has been proposed in several recent studies (Jordan et al. 2018; Yongky et al. 2019). A higher initial seeding cell density (SD) of $\geq 2 \times 10^{6}$ cells $/ \mathrm{mL}$ in fedbatch production bioreactors can be achieved by implementing N-1 perfusion seed culture, which can achieve a much higher final VCD than conventional batch N-1 seed culture. Essentially, the early growth phase for fedbatch production is moved to the $\mathrm{N}-1$ seed culture step, reducing the overall fed-batch production duration with similar final titer but higher volumetric productivity (Padawer et al. 2013; Pohlscheidt et al. 2013; Yang et al.
2014). Two major advantages of this approach (i.e. fedbatch production with $\mathrm{N}-1$ perfusion) over perfusion production $(\mathrm{N})$ culture are: (1) less perfusion medium is required, decreasing the overall raw material cost, and (2) only small changes at the N-1 seed step are required for implementation in existing fed-batch manufacturing facilities.

In this report, we present the development of an intensified fed-batch platform for production of multiple mAbs using CHO K1 GS cell lines. In our previous study, it was demonstrated that production titer could be significantly improved by increasing SD from $\sim 0.5 \times 10^{6}$ to $3-6 \times 10^{6}$ cells $/ \mathrm{mL}$ in the non-perfusion intensified fed-batch process (Yongky et al. 2019). In this study, we increased industrially relevant titers for multiple $\mathrm{mAbs}$ from the non-perfusion intensified fed-batch with $3-6 \times 10^{6}$ cells $/ \mathrm{mL}$ SD by over $100 \%$ by utilizing perfusion N-1 intensified fed-batch with $10-20 \times 10^{6}$ cells $/ \mathrm{mL}$ SD within a 10-14 day bioreactor duration. It was identified that basal and feed optimization by rebalancing all components was critical for high SD fed-batch culture to achieve high titer. In addition, we present data for the intensified processes scaled up in 500-L bioreactors with quality attributes similar to the previous processes in 1000-L bioreactors.

\section{Materials and methods}

\section{Cell line, media and seed expansion}

Four CHO K1 GS cell lines, which were created from the same parental CHO K1 GS cell line, were used for the expression of 4 proprietary human mAbs (mAb1, mAb2, $\mathrm{mAb} 3$, and $\mathrm{mAb} 4)$. Proprietary chemically defined seed, basal, and feed media were used (Table 1). In order to simplify medium preparation, shipment and storage for manufacturing, dry powder media were made by medium vendors and then in house liquid basal and feed media were prepared before cell culture runs by dissolving those dry powder media in deionized water. Vial thaw and seed expansion steps for all 4 cell lines were performed using shake flasks (Corning Life Sciences) containing B1 medium with methionine sulfoximine as a selection agent and cultivated in a humidified incubator (Climo-Shaker, Kuhner) using standard conditions of $36.5{ }^{\circ} \mathrm{C}, 5 \% \mathrm{CO}_{2}$ and $95-150 \mathrm{rpm}$. Cells were passaged every 3-4 days prior to $\mathrm{N}-1$ seed inoculation.

For scale-up runs, N-2 seed cultures were run in WAVE bioreactors with temperature maintained at $36.5^{\circ} \mathrm{C}$. For a non-perfusion WAVE bioreactor, the $\mathrm{N}-2$ seed cultures were cultivated in $50-\mathrm{L}$ cell bags (GE Healthcare) with a $25-\mathrm{L}$ working volume. Rocking speed was controlled at $26 \mathrm{rpm}$ with a $7^{\circ}$ rocking angle. Air and $\mathrm{CO}_{2}$ gas flow rates were properly controlled to ensure good cell growth for a duration of 3 days. For a perfusion N-2 
Table 1 Medium nutrient concentrations used in Process A, Process B and Process C

\begin{tabular}{|c|c|c|c|c|c|}
\hline Medium type & mAb/process & Media name & $\begin{array}{l}\text { Total amino acids } \\
(\mathrm{mM})\end{array}$ & Glucose (g/L) & $\begin{array}{l}\text { Osmolality } \\
(\mathrm{mOsm} / \mathrm{kg})\end{array}$ \\
\hline \multirow[t]{6}{*}{ Basal } & $\begin{array}{l}\text { mAb1/Process A, mAb4/Process A, } \\
\text { mAb3/Process B }\end{array}$ & B1 & 69 & 6 & 300 \\
\hline & mAb1/Process B & B1 enriched1 & 99 & 10 & 380 \\
\hline & mAb2/Process B & B1 enriched2 & 118 & 11 & 410 \\
\hline & mAb3/Process C & B2 & 103 & 6 & 310 \\
\hline & mAb4/Process C & B2 enriched1 & 122 & 10 & 370 \\
\hline & mAb1/Process C, mAb2/Process C & B2 enriched2 & 137 & 10 & 425 \\
\hline \multirow[t]{7}{*}{ Feed } & mAb1/Process A, mAb4/Process A & F1 & 344 & 60 & 1310 \\
\hline & mAb1/Process B & $1.3 \times \mathrm{F} 1$ & 404 & 78 & 1450 \\
\hline & mAb2/Process B & $1.3 \times \mathrm{F} 1$ enriched 1 & 446 & 78 & 1575 \\
\hline & mAb3/Process B & $1.3 \times \mathrm{F} 1$ enriched 2 & 513 & 80 & 1810 \\
\hline & mAb1/Process C & $\mathrm{F} 2$ & 404 & 110 & 1570 \\
\hline & mAb3/Process C, mAb4/Process C & F2 enriched1 & 500 & 120 & 2000 \\
\hline & mAb2/Process C & $1.3 \times \mathrm{F} 2$ enriched 2 & 650 & 156 & 2100 \\
\hline
\end{tabular}

WAVE bioreactor, the seed cultures were cultivated in 50 -L cell bags (GE Healthcare) with a 25 -L working volume. Rocking speed was controlled at $28 \mathrm{rpm}$ with a $7^{\circ}$ rocking angle. Air and $\mathrm{CO}_{2}$ gas flow rates were properly controlled to ensure a good cell growth for a duration of 4 days. The perfusion cell bag was equipped with a $0.2-\mu \mathrm{m}$ filter to perfuse the spent culture medium while retaining the cells. Fresh B1 medium was added continuously and spent culture medium was continuously withdrawn at the same perfusion rates.

\section{N-1 seed cultures}

The cells for batch and enriched batch N-1 seed cultures were grown either in shake flasks, 5-L (glass, Sartorius), 20-L (glass, Applikon) or 200-L bioreactors (single-use Xcellerex, GE Healthcare) depending on scales of fedbatch production bioreactors as described in "Results" section. B1 medium with methionine sulfoximine as a selection agent was used for Process A and Process C, and Process B for mAb3 only, while enriched B1 medium with methionine sulfoximine was used for Process $B$ for $\mathrm{mAb} 1$ and $\mathrm{mAb} 2$. The $\mathrm{N}-1$ bioreactors were run in batch mode for Process A and Process B and in perfusion mode for Process $C$. For perfusion $\mathrm{N}-1$, an auxiliary alternating tangential flow (ATF) device (Repligen) was connected to the bioreactor to perfuse the culture. Stainless steel ATF-2 units were used in lab-scale N-1 perfusion with 5-L and 20-L bioreactors, while single-use ATF-6 units were used in large-scale N-1 perfusion with 200-L bioreactors. Fresh culture medium was continuously added while spent culture medium was continuously removed at the same rate. Perfusion rate was controlled as a function of VCD as measured by an online capacitance probe
(Hamilton). Perfusion was started on Day 1 at a rate of $0.04 \mathrm{~nL} / \mathrm{cell} / \mathrm{day}$ for $\mathrm{mAb} 1, \mathrm{mAb} 2$ and $\mathrm{mAb} 4$ and a rate of $0.08 \mathrm{~nL} /$ cell/day for $\mathrm{mAb3}$. Temperature and dissolved oxygen were maintained at $36.5{ }^{\circ} \mathrm{C}$ and $40 \%$, respectively, and $\mathrm{pH}$ controlled with a setpoint of 7.2.

\section{Fed-batch production cultures}

Fed-batch production bioreactor runs were performed using 5-L, 500-L (single-use Xcellerex, GE Healthcare) and 1000-L (single-use Xcellerex, GE Healthcare) bioreactors for 14 days unless otherwise specified. Basal and feed media for production cultures are summarized in Table 1. Dissolved oxygen was maintained at $40 \%$ and $\mathrm{pH}$ was controlled at a setpoint of $\mathrm{pH}$ 7.1-7.2 using $1 \mathrm{M}$ $\mathrm{Na}_{2} \mathrm{CO}_{3}$ and $\mathrm{CO}_{2}$ gas. Other bioreactor conditions are as described in "Results" section.

\section{In-process cell culture and quality attribute assays}

Cell culture broth was sampled from each bioreactor daily and directly analyzed for gases, cell count, nutrients, and metabolites. Offline $\mathrm{pH}, \mathrm{pCO}_{2}$ and $\mathrm{pO}_{2}$ were measured using a Bioprofile pHOx analyzer (Nova Biomedical). VCD and cell viability were quantified off-line using a Vi-CELL XR automatic cell counter (Beckman Coulter). Glucose, glutamine, glutamate, lactate, and ammonia were quantified using a CEDEX Bio HT analyzer (Roche).

For titer measurements, the cell culture broth was centrifuged at $500-1000 \mathrm{~g}$ for $5-10 \mathrm{~min}$, and the supernatant was analyzed using a Protein A UPLC method. The normalized titer, expressed as normalized weight/L, was equal to the true titer $(\mathrm{g} / \mathrm{L})$ at each time point divided by the average of final (Day 14) Process C titer $(\mathrm{g} / \mathrm{L}$ ) at 500-L scale for mAb1 and mAb3, by the average of Day 10 
Process $\mathrm{C}$ titer at 5 -L scale for $\mathrm{mAb} 2$, or by the final (Day 12) Process $C$ titer at $500-\mathrm{L}$ scale for $\mathrm{mAb} 4$, respectively. Overall cell specific productivity (normalized weight/ cell/day) and overall volumetric productivity (normalized weight/L/day) were calculated based on normalized titers. Overall cell specific productivity and overall volumetric productivity or space time yield were calculated according to the literature (Bausch et al. 2019).

Similar methods as described in our previous report (Yongky et al. 2019) were used for in-process quality attributes. For example, charge variant species (acidic, main and basic) were measured by imaged capillary isoelectric focusing for $\mathrm{mAb} 1, \mathrm{mAb} 2$, and $\mathrm{mAb} 3$ and by cation exchange (CEX) liquid chromatography for mAb4. N-Glycan profiles (e.g. G0, G0F, G1F, G2F and Man5) were measured using a commercially available RapiFluor-MS N-Glycan kit from waters. Size exclusion chromatography was used to measure high molecular weight (HMW) and low molecular weight (LMW). Prior to quality measurements, the supernatant samples were purified by Protein A chromatography.

\section{Results \\ Platform evolution of fed-batch process intensification for mAb manufacturing}

In this study, we developed an intensified fed-batch process platform for cell culture manufacturing of stable mAbs. As shown in Table 2, the development of a cell culture platform started from the conventional fedbatch Process A with $0.3-1.5 \times 10^{6}$ cells $/ \mathrm{mL}$ SD, which typically achieved a normalized titer of $0.1-0.3$ (normalized to the titers observed in the intensified Process C). The N-1 seed culture was run in batch mode for the conventional fed-batch Process A (Table 2). Next, an intensified platform fed-batch Process $\mathrm{B}$ was developed with 3.0-6.0 $\times 10^{6}$ cells $/ \mathrm{mL}$ SD, which typically achieved a normalized titer of $\sim 0.5$ (Table 2 ). The $\mathrm{N}-1$ seed culture was run in a batch mode with enriched seed medium in order to inoculate the production fed-batch culture at a higher SD than in the conventional fed-batch Process A (Table 2). More detailed development data for the nonperfusion intensified fed-batch platform were presented in our previous report (Yongky et al. 2019). In this report, detailed data on the development of a further intensified platform fed-batch Process $\mathrm{C}$ are presented with $10-20 \times 10^{6}$ cells $/ \mathrm{mL}$ SD, which achieved a normalized titer of 1.0 (Table 2). To inoculate the production bioreactors at $10-20 \times 10^{6}$ cells $/ \mathrm{mL} \mathrm{SD}$, the N-1 seed culture was run in a perfusion mode (Table 2 ).

In addition to increasing $\mathrm{SD}$, efforts on medium development were required to support the higher SD and the significant titer improvement (Tables 1 and 2). B1 basal and F1 feed were used for Process A, e.g. Process A for production of $\mathrm{mAb} 1$ and mAb4 (Table 1). Process $B$ media composed of the same base formulation as B1 and F1 using the same dry powder media, but with typically increased component concentrations compared to the Process A formulations and with varied ratios of the dry powders for the production of the different mAbs (i.e., B1 enriched1 and B1 enriched2; Table 1). Medium development from Process A to Process B was performed by analyzing spent medium data, increasing concentrations of components depleted during the production culture, and enriching or concentrating basal and feed formulations. Using mAb1 as an example, the basal was enriched from Process A to Process B: total amino acids

Table 2 Cell culture platform evolution from conventional to intensified fed-batch production

\begin{tabular}{|c|c|c|c|c|}
\hline Category & Parameter & Process A & Process B & Process C \\
\hline \multirow[t]{3}{*}{ Media } & Seed expansion & $\mathrm{B} 1+\mathrm{MSX}$ & $\mathrm{B} 1+\mathrm{MSX}$ & $\mathrm{B} 1+\mathrm{MSX}$ \\
\hline & Production basal & B1 & $\mathrm{B} 1$ or $\mathrm{B} 1$ enriched & B2 or B2 enriched \\
\hline & Feed & $\mathrm{F} 1$ & $1.3 \times \mathrm{F} 1$ or $1.3 \times \mathrm{F} 1$ enriched & F2 or F2 enriched \\
\hline \multirow[t]{3}{*}{ Process mode } & $\mathrm{N}-2$ seed & Batch & Batch & Perfusion or batch \\
\hline & $N-1$ seed & Batch & Enriched batch or fed-batch & Perfusion \\
\hline & Production (N) & Conventional fed-batch & $\begin{array}{l}\text { Intensified fed-batch with non- } \\
\text { perfusion N-1 }\end{array}$ & $\begin{array}{l}\text { Intensified fed- } \\
\text { batch with perfu- } \\
\text { sion N-1 }\end{array}$ \\
\hline \multirow[t]{3}{*}{$\begin{array}{l}\text { Production process } \\
\text { parameters }\end{array}$} & $\begin{array}{l}\text { Inoculation density }\left(\times 10^{6}\right. \\
\text { cells } / \mathrm{mL})\end{array}$ & $0.3-1.5$ & $3.0-6.0$ & $10-20$ \\
\hline & Feeding strategy & $\begin{array}{l}\text { Fixed at } 3.6 \% \text { of initial volume } \\
\text { from Day } 3\end{array}$ & Variable & Variable \\
\hline & Temperature shift & No & Variable & Variable \\
\hline Harvest & Day & Day 14 & Day 10-14 & Day 10-14 \\
\hline Process yield & Final normalized titer & $0.1-0.3$ & $\sim 0.5$ & $\sim 1.0$ \\
\hline
\end{tabular}


increased from 69 to $99 \mathrm{mM}$, glucose increased from 6 to $10 \mathrm{~g} / \mathrm{L}$ and osmolality increased from 300 to $380 \mathrm{mOsm} /$ $\mathrm{kg}$ from Process A to Process B (Table 1). Similarly, the feed for mAb1 was enriched from Process A to Process B: total amino acids increased from 344 to $404 \mathrm{mM}$, glucose increased from 60 to $78 \mathrm{~g} / \mathrm{L}$ and osmolality increased from 1310 to $1450 \mathrm{mOsm} / \mathrm{kg}$ from Process A to Process B (Table 1). In addition to mAb1, Process B basal and feed media were developed with similar strategies for mAb2 and mAb3 production with approximately 6-9 months for each project before 1000-L manufacturing.

In order to support the continued increase in SD from Process $\mathrm{B}\left(\mathrm{SD}=3.0\right.$ to $6 \times 10^{6}$ cells $\left./ \mathrm{mL}\right)$ to Process $\mathrm{C}$ $\left(\mathrm{SD}=10\right.$ to $20 \times 10^{6}$ cells $/ \mathrm{mL}$ ), more significant medium development efforts were required rather than simply increasing the concentration of most components. The base formulations for the platform Process C basal (B2) use new dry powder media that were rebalanced when compared to the enriched B1 formulations in Process B. Overall, changes were made to the concentrations of 52 individual components, including addition or removal of some components and increasing or decreasing concentrations for others. For example, the enriched B1 for $\mathrm{mAb} 1$ Process $\mathrm{B}$ had similar concentrations of total amino acids to the $\mathrm{B} 2$ used for $\mathrm{mAb} 3$ Process $\mathrm{C}$; however, the concentrations of vitamins, lipids, salts and other components were rebalanced leading to significant differences in final osmolality (Table 1). In parallel, similar rebalance work was carried out to develop a new feed F2 from F1. For example, F2 for Process C and enriched F1 for Process $\mathrm{B}$ had similar total amino acid concentrations of $404 \mathrm{mM}$ for mAb1, but F2 had a higher osmolality (Table 1) with changes in the concentrations of more than 30 components. After rebalancing, the new media B2 and F2 or enriched or concentrated derivatives were suitable for the high SD cultures leading to significantly titer improvements when compared to previous processes, as shown in following case studies for production of $4 \mathrm{mAbs}$.

In addition to SD and medium development, other cell culture process parameters such as feeding strategies and temperature shift played positive roles during process development. A detailed strategy for how to optimize temperature shift conditions is published in our previous report (McHugh et al. 2020). Although temperature shift may not be required for conventional fed-batch with only $0.3-1.5 \times 10^{6}$ cells $/ \mathrm{mL} \mathrm{SD}$, temperature shift may be required for many intensified fed-batch processes with $3-20 \times 10^{6}$ cells $/ \mathrm{mL}$ SD. In general, a higher nutrient strength was required to maintain healthy cultures at higher SD, typically leading to an earlier feed start date with a larger feed volume. In addition, since the cell growth phase was shortened in the early stages of the intensified Process $\mathrm{C}$, temperature shift was typically on an earlier day or to a lower temperature for Process $\mathrm{C}$ than for Process B. In order to maximize titer for each process, the process parameters for Process B or Process $\mathrm{C}$ were optimized in lab before scale-up runs in 500-L or 1000-L bioreactors for each of $4 \mathrm{mAbs}$, as presented below.

\section{Intensified Process $C$ development for $\mathrm{mAb} 1$ production Comparison of $m A b 1$ Process $B$ in 1000-L bioreactors and Process $C$ in $500-L$ bioreactors}

The large-scale bioreactor performance for $\mathrm{N}-1$ seed and fed-batch production bioreactors, and the in-process quality attributes are presented in Fig. 1 for mAb1 Process $B$ and Process $C$. The changes made from mAb1 Process $\mathrm{B}$ to Process $\mathrm{C}$ are summarized in Table 3. For $\mathrm{N}-1$ cultures, the perfusion seed culture achieved a much higher final VCD of about $100 \times 10^{6}$ cells $/ \mathrm{mL}$ for Process $\mathrm{C}$ when compared with the enriched batch $\mathrm{N}-1$ culture which achieved a final VCD of about $16 \times 10^{6}$ cells $/ \mathrm{mL}$ for Process B (Fig. 1a). Due to the high final VCD for the perfusion $\mathrm{N}-1$ seed, the viability dropped to about $95 \%$ on Day 6, while the enriched batch N-1 seed for Process B maintained cell viability above $99 \%$ for the entire 4-day duration (Fig. 1b). In the production bioreactor, the VCD for Process $C$ with $16 \times 10^{6}$ cells $/ \mathrm{mL}$ SD was not only much higher in the beginning of culture than the VCD for Process $\mathrm{B}$, but Process $\mathrm{C}$ also maintained higher VCD through the entire 14-day duration (Fig. 1c). Due to lower viability at the end of the perfusion N-1 step for Process $C$ (Fig. 1b), the viability for Process $C$ was slightly lower than in Process $B$ at the beginning of the fed-batch production, but the Process $\mathrm{C}$ viability increased and trended similarly to Process B from Day 2 on (Fig. 1d). There was a viability dip in the middle of the run for Process B, which was not seen for Process C (Fig. 1d). The improved cell VCD and viability profiles for Process $C$ may be due to the rebalanced and enriched basal and feed media as cell culture media is generally considered a critical factor in affecting cell growth (Table 1). Importantly, the titer for Process $\mathrm{C}$ was approximately doubled compared to the titer of Process $B$ throughout the entire 14-day duration (Fig. 1e), while in-process quality attributes, e.g. charge variant species, N-glycans, and SEC impurities, were similar between Process B and C (Fig. 1f). The doubled titer and volumetric productivity for mAb1 Process $C$ compared with Process $B$ can be attributed to both higher VCD and higher cell specific productivity (Table 4).

It should be noted that Process B had been optimized using 6 runs of high-throughput screening with $96 \times 50-\mathrm{mL}$ TubeSpin bioreactors per run and 14 runs of 6-12 lab-scale (5-L) bioreactors per run over 

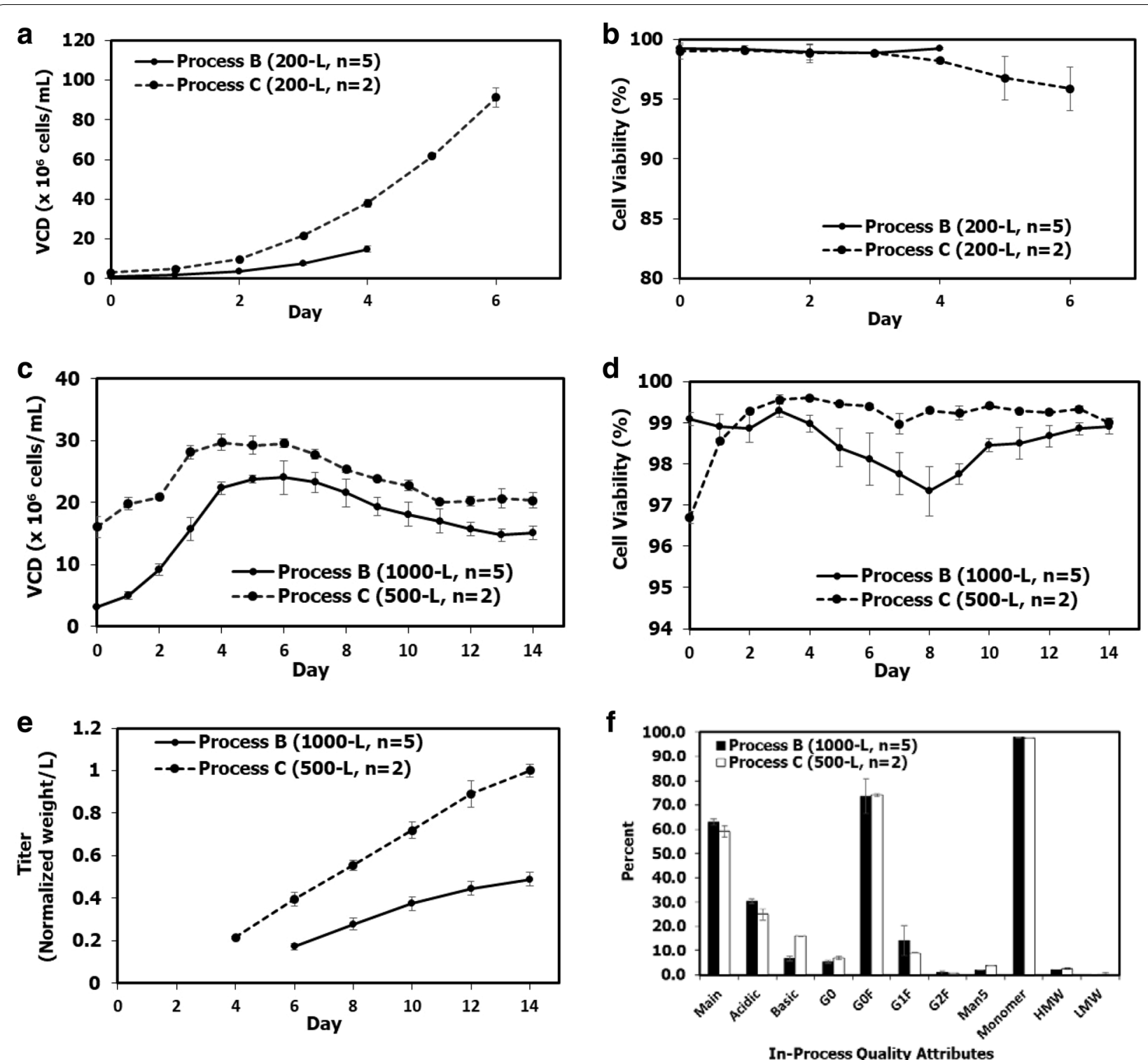

Fig. 1 a Viable cell density (VCD) and $\mathbf{b}$ cell viability profiles for the batch $N-1$ seed at 200-L scale for Process B and the perfusion $N-1$ seed at 200-L scale for Process $C_{;} \mathbf{c} V C D ; \mathbf{d}$ cell viability; e normalized titer, and $\mathbf{f}$ in-process quality attribute profiles on Day 14 at harvest for the subsequent fed-batch cell culture performance using Process B in 1000-L bioreactors and Process C in 500-L bioreactors for mAb1 production. The maximum titer on Day 14 for Process C at 500-L scale was normalized as 1 for mAb1. Process B values are reported as average \pm standard deviation $(n=5)$, while Process $C$ values are reported as average \pm difference/2 $(n=2)$

more than 6 months before the 1000-L large-scale runs, as described previously. The critical changes from Process $B$ to $C$, i.e., significantly higher SD at $16 \times 10^{6}$ cells $/ \mathrm{mL}$ and rebalanced media, resulted in the significant improvement of titer in Process C, which is further discussed in the section below.

\section{Effect of SD and media on mAb1 cell culture performance} using different processes in 5-L bioreactors

In order to understand the effects of SD and media on cell culture performance for mAb1 production, a more systematic study was performed with different production inoculation cell densities, media and process conditions using the same $\mathrm{N}-1$ seed source run at perfusion mode (Table 5). To accommodate different SD and medium strengths, feed start dates and temperature shift timing were adjusted for different 5 -L bioreactor conditions 
Table 3 Changes in Process C for different mAb production

\begin{tabular}{|c|c|c|c|c|c|c|c|c|}
\hline \multirow{2}{*}{$\begin{array}{l}\text { mAb } \\
\text { Process }\end{array}$} & \multicolumn{2}{|l|}{ mAb1 } & \multicolumn{2}{|l|}{$\mathrm{mAb2}$} & \multicolumn{2}{|l|}{$\mathrm{mAb3}$} & \multicolumn{2}{|l|}{ mAb4 } \\
\hline & B & $\mathrm{C}$ & B & $\mathrm{C}$ & B & $\mathrm{C}$ & A & $C$ \\
\hline $\mathrm{N}-2$ seed & $\begin{array}{l}\text { Batch in } 50-L \\
\text { wave }\end{array}$ & $\begin{array}{l}\text { Perfusion in } \\
50-L \text { wave }\end{array}$ & $\begin{array}{l}\text { Batch in } 50-L \\
\text { wave }\end{array}$ & Shake flasks & $\begin{array}{l}\text { Batch in } 50-L \\
\text { wave }\end{array}$ & $\begin{array}{l}\text { Perfusion in } \\
50-L \text { wave }\end{array}$ & $\begin{array}{l}\text { Batch in } 50-L \\
\text { wave }\end{array}$ & $\begin{array}{l}\text { Perfusion in } \\
50-L \text { wave }\end{array}$ \\
\hline N-1 seed & Batch in 200-L & $\begin{array}{l}\text { Perfusion in } \\
200-L\end{array}$ & Batch in 200-L & $\begin{array}{l}\text { Perfusion in } \\
20-L\end{array}$ & Batch in 200-L & $\begin{array}{l}\text { Perfusion in } \\
200-L\end{array}$ & Batch in 200-L & $\begin{array}{l}\text { Perfusion in } \\
200-L\end{array}$ \\
\hline $\begin{array}{l}\text { Fed-batch } \\
\text { production }\end{array}$ & $1000-\mathrm{L}$ & $500-L$ & $1000-L$ & $5-L$ & $1000-L$ & $500-\mathrm{L}$ & $1000-L$ & $500-L$ \\
\hline $\begin{array}{c}\mathrm{SD}\left(\times 10^{6}\right. \\
\text { cells } / \mathrm{mL})\end{array}$ & 3.0 & 16 & 3.0 & 15 & 4.5 & 10 & 1.5 & 15 \\
\hline Feed rate & $\begin{array}{l}\text { Fixed at } 3.1 \% \\
\text { of initial } \\
\text { volume from } \\
\text { Day } 4 \text { (D4) }\end{array}$ & $\begin{array}{l}\text { Fixed at } 4.1 \% \\
\text { of initial vol- } \\
\text { ume from D2 }\end{array}$ & $\begin{array}{l}\text { Fixed at } 3.5 \% \\
\text { of current } \\
\text { volume from } \\
\text { D3 }\end{array}$ & $\begin{array}{l}\text { Fixed at } 4 \% \\
\text { from current } \\
\text { volume D1 }\end{array}$ & $\begin{array}{l}2.6 \% \text { D2-3; } \\
3.5 \% \text { D4-8; } \\
2.46 \% \text { D9-13 } \\
\text { of initial } \\
\text { volume }\end{array}$ & $\begin{array}{l}\text { 2.6\% D1; } \\
3.54 \% \\
\text { D2-13; initial } \\
\text { volume }\end{array}$ & $\begin{array}{l}\text { Fixed at } 3.6 \% \\
\text { of initial } \\
\text { volume } \\
\text { from D3 }\end{array}$ & $\begin{array}{l}\text { Fixed at } 4.5 \% \text { of } \\
\text { initial volume } \\
\text { from D1 }\end{array}$ \\
\hline $\begin{array}{l}\text { Temperature } \\
\text { shift to }\end{array}$ & $32^{\circ} \mathrm{C}$ on D5 & $32{ }^{\circ} \mathrm{C}$ on D3 & $34{ }^{\circ} \mathrm{C}$ on D6 & $34{ }^{\circ} \mathrm{C}$ on D4 & NA & NA & NA & $34{ }^{\circ} \mathrm{C}$ on D4 \\
\hline
\end{tabular}

Table 4 Cell culture performance comparison between fed-batch Process C and Process A or B for different mAb production on Day 14 unless otherwise specified

\begin{tabular}{|c|c|c|c|c|c|}
\hline Product & Process at bioreactor scale & $\begin{array}{l}\text { Titer } \\
\text { (normalized } \\
\text { weight/L) }\end{array}$ & $\begin{array}{l}\text { Peak VCD } \\
\left(\times 10^{6} \text { cells } /\right. \\
\mathrm{mL})\end{array}$ & $\begin{array}{l}\text { Cell specific productivity } \\
\text { (normalized weight/cell/day) }\end{array}$ & $\begin{array}{l}\text { Volumetric productivity } \\
\text { (normalized weight/L/ } \\
\text { day) }\end{array}$ \\
\hline \multirow[t]{2}{*}{ mAb1 } & B at $1000-\mathrm{L}(n=5)$ & $0.5 \pm 0.03$ & $24.0 \pm 2.7$ & $2.05 \pm 0.20$ & $0.035 \pm 0.002$ \\
\hline & C at $500-L(n=2)$ & $1.00 \pm 0.02$ & $29.7 \pm 1.3$ & $2.98 \pm 0.06$ & $0.071 \pm 0.002$ \\
\hline \multirow[t]{2}{*}{ mAb2 on Day 10} & B at 1000-L $(n=5)$ & $0.50 \pm 0.02$ & $19.5 \pm 1.1$ & $3.03 \pm 0.21$ & $0.042 \pm 0.002$ \\
\hline & $C$ at $5-L(n=4)$ & $1.00 \pm 0.01$ & $33.4 \pm 1.6$ & $3.04 \pm 0.07$ & $0.084 \pm 0.001$ \\
\hline \multirow[t]{2}{*}{ mAb3 } & B at $1000-\mathrm{L}(n=3)$ & $0.53 \pm 0.02$ & $22.3 \pm 0.3$ & $2.24 \pm 0.05$ & $0.034 \pm 0.000$ \\
\hline & C at $500-L(n=2)$ & $1.00 \pm 0.05$ & $40.9 \pm 5.0$ & $2.41 \pm 0.36$ & $0.071 \pm 0.001$ \\
\hline \multirow[t]{3}{*}{ mAb4 } & A at 1000-L $(n=5)$ & $0.31 \pm 0.03$ & $32.9 \pm 2.7$ & $1.05 \pm 0.14$ & $0.022 \pm 0.002$ \\
\hline & C at $5-\mathrm{L}(n=4)$ & $1.00 \pm 0.02$ & $42.3 \pm 1.3$ & $2.28 \pm 0.08$ & $0.071 \pm 0.002$ \\
\hline & C at 500-L on Day $12(n=1)$ & 1.00 & 47 & 2.24 & 0.083 \\
\hline
\end{tabular}

The Process C final titer at 500-L scale was normalized as 1 for each of mAb1, mAb3 and mAb4, while the Process C titer at 5-L scale on Day 10 was normalized as 1 for mAb2

Table 5 Experimental design for the study of effects of inoculation cell densities and media on mAb1 production in fedbatch 5 -L bioreactors $(n=2)$

\begin{tabular}{|c|c|c|c|c|c|c|c|c|}
\hline \multirow[t]{2}{*}{ Parameters } & & \multicolumn{7}{|l|}{ Conditions } \\
\hline & & 1 & 2 & 3 & 4 & 5 & 6 & 7 \\
\hline Inoculum & $\begin{array}{l}\text { Inoculation seeding den- } \\
\text { sity }(\mathrm{SD})\left(\times 10^{6} \text { cells } / \mathrm{mL}\right)\end{array}$ & 1.5 & 3 & 11 & 19 & 3 & 11 & 19 \\
\hline \multirow[t]{2}{*}{ Media } & Basal & Process A (B1) & Process B (B1 enriched1) & & & Process C (B2 enriched2) & & \\
\hline & Feed & Process A (F1) & Process B $(1.3 \times F 1)$ & & & Process C (F2) & & \\
\hline \multirow[t]{2}{*}{ Feeding strategy } & Daily feed rate & \multicolumn{7}{|c|}{$3.6 \%$ of initial volume } \\
\hline & Feed start day & 3 & 4 & 2 & 1 & 4 & 2 & 1 \\
\hline Bioreactor condition & Temperature shift to $32^{\circ} \mathrm{C}$ & NA & Day 5 & Day 4 & Day 3 & Day 5 & Day 4 & Day 3 \\
\hline
\end{tabular}


based on our empirical experience (Table 5). In general, the conditions with higher SD had earlier feed start dates and earlier temperature shifts (Table 5).
For Process $\mathrm{B}$ medium conditions, the VCD values increased with increasing SD for the first half of the bioreactor duration, and the higher SD cultures reached their peak VCD at an earlier time (solid lines
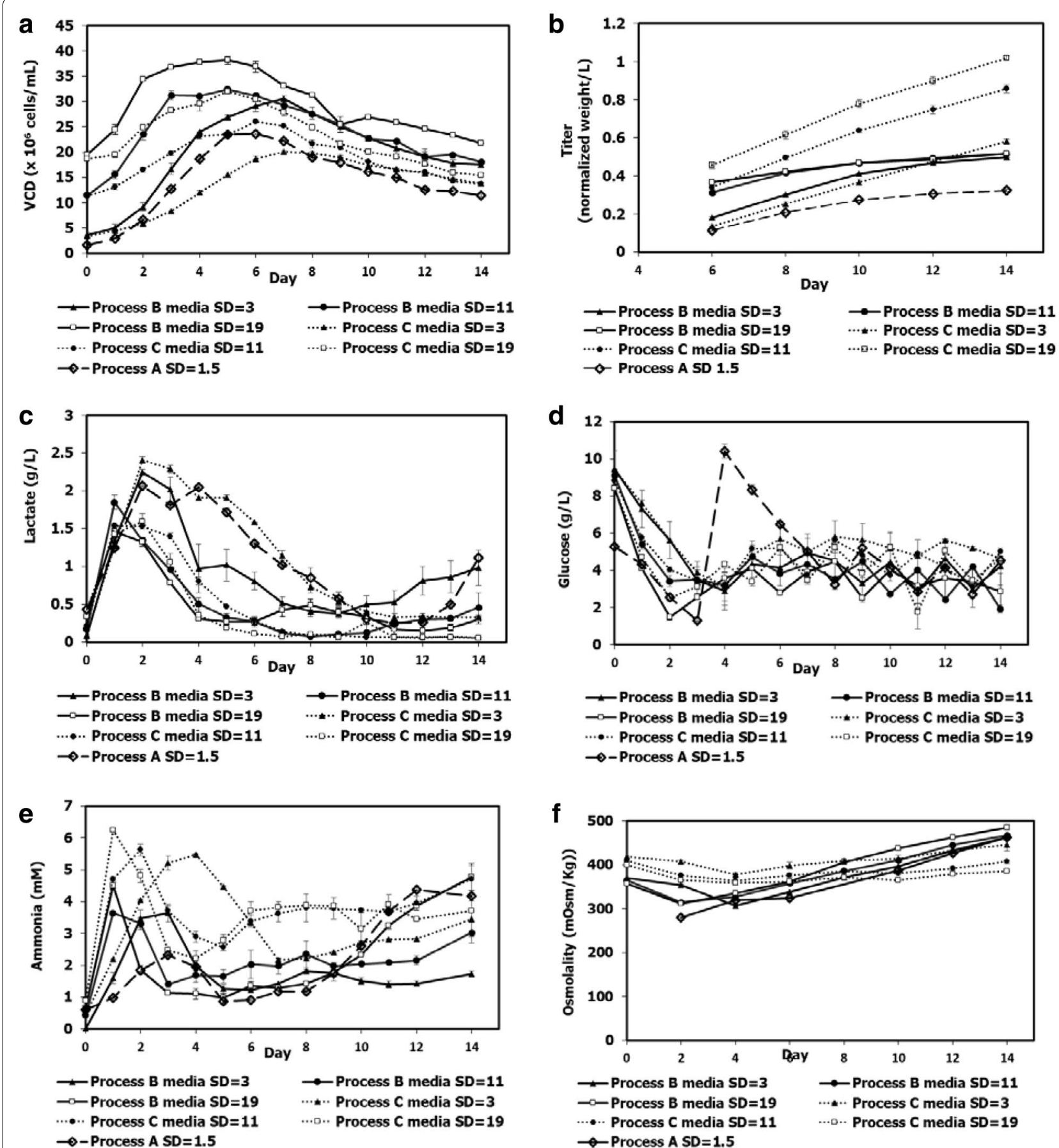

Fig. 2 a Viable cell density (VCD) and $\mathbf{b}$ normalized titer profiles for the fed-batch cell culture performance using different media (Process A, B and $C)$ and inoculation seeding density (SD) in 5-L bioreactors for mAb1 production. The maximum titer on Day 14 for Process $C$ at $500-L$ scale was normalized as 1 for mAb1, as described in Fig. 1 legend. Values are reported as average \pm difference/2 $(n=2)$ 
in Fig. 2a). For Process $\mathrm{C}$ medium conditions, similar results were observed (dotted lines in Fig. 2a). However, Process $\mathrm{C}$ medium conditions had generally lower VCD than Process B medium conditions using the same SD (Fig. 2a), which can be attributed to the fact that Process $\mathrm{C}$ media with higher nutrient strength and osmolality (Table 1) inhibits cell growth but increases cell specific productivity (Table 4). The Process A VCD profile with $1.5 \times 10^{6}$ cells $/ \mathrm{mL}$ SD was between Process $\mathrm{B}$ and Process $\mathrm{C}$ conditions using $3 \times 10^{6}$ cells $/ \mathrm{mL} \mathrm{SD}$ (Fig. 1a). The different VCD profiles for different conditions were contributed by overall effects of different media, SD, feeding strategies and temperature shift conditions.

There was a clear trend of increasing titer from Process A (dashed line), to Process B (solid lines) and to Process C (dotted lines) (Fig. 2b), which was attributed to the combination of increasing SD and medium optimization (Table 1). Increasing SD alone did not increase final titer, but achieved the final titer at a shorter culture duration for the Process $\mathrm{B}$ medium conditions (three solid lines in Fig. 2b). This was in agreement with many other reports that claim that increasing SD significantly shortened the culture duration (Padawer et al. 2013; Pohlscheidt et al. 2013; Yang et al. 2014). Interestingly, the change in media from Process $\mathrm{B}$ to Process $\mathrm{C}$ alone did not improve titer drastically either, when SD was maintained at the relatively low value of $3 \times 10^{6}$ cells $/ \mathrm{mL}$ (Fig. $2 \mathrm{~b}$ ). The significant titer improvements observed between the Process B and the Process $C$ platforms require both the increase in SD from 3 to $10-20 \times 10^{6}$ cells $/ \mathrm{mL}$ as well as the medium concentration and rebalancing efforts that went into generating the Process $\mathrm{C}$ media (Fig. 2b). Although there was a minimal effect of SD on final titer using Process $B$ media (solid lines, Fig. 2b), each increase in SD for the Process $\mathrm{C}$ medium conditions led to an increase in final titer (dotted lines, Fig. 2b).

Other measured metabolites and process parameters were in safe cell culture ranges for all conditions, including lactate $(<2.5 \mathrm{~g} / \mathrm{L}$, Fig. $2 \mathrm{~b})$, glucose $(2-6 \mathrm{~g} / \mathrm{L}$ after dropping from the initial value of $\sim 9$ g/L, Fig. $2 \mathrm{~d}$ ), ammonia (< $6 \mathrm{mM}$, Fig. 2e), and osmolality $(<500 \mathrm{mOsm} /$ $\mathrm{kg}$, Fig. 2f). The exception was observed for glucose at $\sim 10 \mathrm{~g} / \mathrm{L}$ on Day 4 due to an operation issue for the Process A condition (Fig. 2d), which did not cause lactate buildup (Fig. 2c). Therefore, the differences in VCD (Fig. 2a) and titer profiles (Fig. 2b) were not caused by excessive buildup of these metabolites or osmolality.
Intensified Process $\mathrm{C}$ development for $\mathrm{mAb2}$ production Comparison of $m A b 2$ Process $B$ in 1000- $L$ bioreactors and Process $C$ in $5-L$ bioreactors

The comparison of Process $B$ and $C$ is shown in Fig. 3 for mAb2 production. The N-1 seed culture for Process $C$ reached much higher final VCD because of perfusion (Fig. 3a), while the cell viability profiles were similar (Fig. 3b).

Both 1000-L runs and 5-L satellite runs using the same 200-L N-1 seed for Process B achieved similar VCD (Fig. 3c), viability (Fig. 3d) profiles, and almost exactly the same titer profiles (Fig. 3e). This indicates that there is comparable performance at $5-\mathrm{L}$ and $1000-\mathrm{L}$ scale for mAb2 Process B. In fact, there were not any significant issues during scale up of Process A, Process B and Process $C$ from lab to large scales for all mAbs in this study (data not shown). The VCD in fed-batch production for Process $C$ was much higher than the VCD in the fedbatch production for Process B (Fig. 3c). Although the viability for Process $C$ was slightly lower than Process $\mathrm{B}$, the viability for both processes remained high (above 95\%) until Day 10 (Fig. 3d). Process $C$ achieved approximately double the titer of Process $B$ for the entire culture duration (Fig. 3e). The increased titer and volumetric productivity in Process $C$ were mainly attributed to significantly higher VCD in the production stage, since the cell specific productivities were comparable between Process B and Process C (Fig. 3 and Table 4).

The changes from Process $B$ to Process $C$ for mAb2 are shown in Table 3. Similar to mAb1, Process B for mAb2 had been well developed, using many high-throughput runs with 96 50-mL TubeSpin bioreactors per run and lab 5-L runs for about 6 months before mAb2 1000-L runs (data not shown). Two major changes from Process B to Process C, e.g. increased SD at $15 \times 10^{6}$ cells $/ \mathrm{mL}$ and the rebalanced media with new dry powder media, were not tested during Process B development. The higher SD kept VCD higher at the beginning of cell culture, while rebalanced enriched B2 and rebalanced enriched F2 sustained higher VCD through the entire production bioreactor duration for Process $\mathrm{C}$ than Process B.

\section{Effect of different $\mathrm{N}-1$ modes, SD and media on $\mathrm{mAb2}$ cell culture performance in $5-L$ bioreactors}

Although the same platform CHO K1 GS parental cell line was used for the cell line creation of all $4 \mathrm{mAbs}$, some differences in cell culture performance often exist for production of different mAbs, which could require different media and bioreactor conditions. Therefore, the effect of SDs and different media compositions including the optimized media for the cell lines producing $\mathrm{mAb} 1$ and $\mathrm{mAb} 2$ were studied for production of mAb2. For the same SD of $15 \times 10^{6}$ cells $/ \mathrm{mL}$, condition 1 with B2 

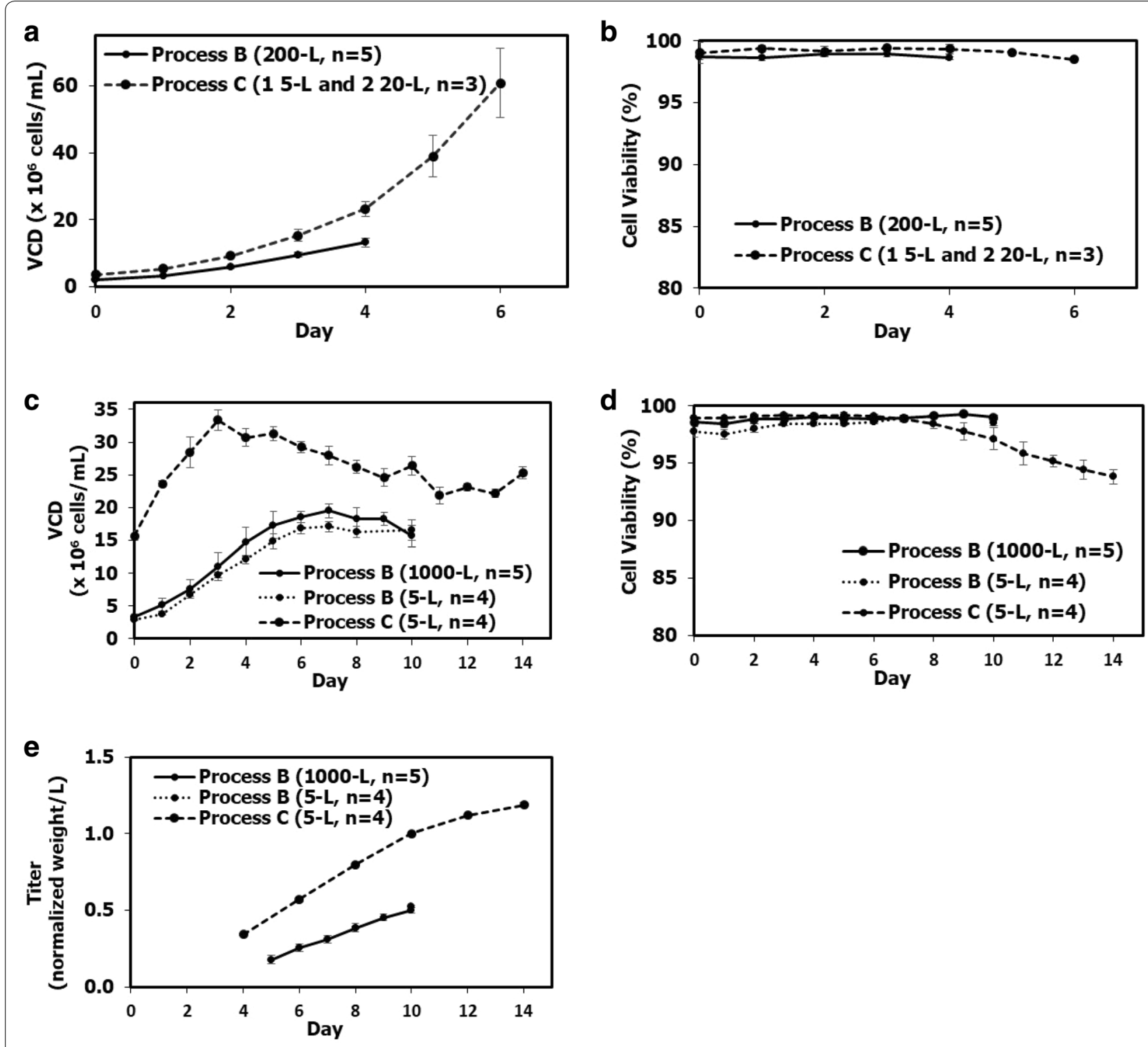

Fig. 3 a Viable cell density (VCD) and $\mathbf{b}$ cell viability profiles for the enriched N-1 seed at 200-L scale $(n=5)$ for Process B and the perfusion N-1 seed at lab scales $(n=3)$ for Process $C ; \mathbf{c} V C D$; $\mathbf{d}$ cell viability, and e normalized titer profiles for the subsequent fed-batch cell culture performance using Process B in 1000-L bioreactors $(n=5)$, Process B in 5-L satellite bioreactors $(n=4)$ using the same N-1 seed as $1000-\mathrm{L}$ and Process $C$ in 5-L bioreactors $(n=4)$ for $\mathrm{mAb} 2$ production. The titer on Day 10 for Process $C$ at 5 - $\mathrm{L}$ scale was normalized as 1 for mAb2. Values are reported as average \pm standard deviation $(n \geq 3)$

enriched2 and $1.3 \times$ F2 enriched2 (i.e., the lead condition for mAb2 Process C) media gave the highest normalized titer at 1.19, while condition 2 with B2 enriched2 and F2 (i.e., the lead condition for $\mathrm{mAb} 1$ Process $\mathrm{C}$ ) and condition 3 with $\mathrm{B} 1$ enriched 2 and $1.3 \times \mathrm{F} 1$ enriched1 (i.e., the lead condition for $\mathrm{mAb} 2$ Process $\mathrm{B}$ ) gave similar normalized titers of $0.78-0.8$ (Table 6). The basal for mAb1 and mAb2 Process C (B2 enriched2) had $137 \mathrm{mM}$ total amino acids which was higher than the $118 \mathrm{mM}$ total amino acids in the basal of mAb2 Process B (B1 enriched2).
However, the feed for mAb1 Process C (F2) had $404 \mathrm{mM}$ amino acids, which was lower than $446 \mathrm{mM}$ amino acids for the feed of mAb2 Process B $(1.3 \times \mathrm{F} 1$ enriched1; Table 1). Thus, total amino acid content was higher in the basal for condition 2 (B2 enriched2 and F2) and higher in the feed for condition 3 (B1 enriched2 and $1.3 \times \mathrm{F} 1$ enriched1), leading to similar medium nutrient strengths overall and likely contributing to the similar titers observed in these 2 conditions (Table 6). In comparison, the optimized basal and feed media for mAb2 Process $C$ 
Table 6 Normalized titers on Day 14 for $\mathrm{mAb2}$ production using different $\mathbf{N}-1$ seed cultures, production inoculation cell densities (SD) and media in 5-L fed-batch bioreactors

\begin{tabular}{|c|c|c|c|c|c|c|}
\hline Condition & $1(n=4)$ & $2(n=2)$ & $3(n=2)$ & $4(n=1)$ & $5(n=2)$ & $6(n=2)$ \\
\hline $\mathrm{N}-1$ mode & Perfusion & Perfusion & Perfusion & Perfusion & Enriched batch & Enriched batch \\
\hline $\mathrm{SD}\left(\times 10^{6}\right.$ cells $\left./ \mathrm{mL}\right)$ & 15 & 15 & 15 & 3 & 3 & 3 \\
\hline Basal & B2 enriched2 & B2 enriched2 & B1 enriched2 & B2 enriched2 & B2 enriched2 & B1 enriched2 \\
\hline Feed & $1.3 \times$ F2 enriched 2 & $\mathrm{~F} 2$ & $1.3 \times$ F1 enriched 1 & $\mathrm{~F} 2$ & $\mathrm{~F} 2$ & $1.3 \times \mathrm{F} 1$ enriched 1 \\
\hline Titer (normalized weight/L) & $1.19 \pm 0.02$ & $0.8 \pm 0.01$ & $0.78 \pm 0.03$ & 0.24 & $0.39 \pm 0.07$ & $0.64 \pm 0.01$ \\
\hline
\end{tabular}

The Process $C$ titer on Day 10 was normalized as 1 for mAb2

contained the highest amino acid concentrations among all media tested (Table 1), which was a reason why condition 1 achieved the highest titer (Table 6). In comparison to $\mathrm{mAb} 1$, the $\mathrm{mAb} 2$ cell line required more nutrients for optimal growth and protein production.

Another interesting phenomenon was that condition 6 with $\mathrm{B} 1$ enriched2 and $1.3 \times \mathrm{F} 1$ enriched1 (i.e., mAb2 Process B media) achieved much higher titer in comparison to condition 5 with $\mathrm{B} 2$ enriched 2 and F2 (i.e., mAb1 Process $C$ media), when SD was at $3 \times 10^{6}$ cells $/ \mathrm{mL}$ using a batch $\mathrm{N}-1$ seed with enriched media (Table 6). This is consistent with the data for mAb1 obtained at the lower SD of $3 \times 10^{6}$ cells/mL suggesting that Process $\mathrm{C}$ media may not always be superior to Process $B$ media (Fig. 2). In addition, condition 4 with the perfusion $\mathrm{N}-1$ seed achieved a lower titer than condition 5 with the batch $\mathrm{N}-1$ seed using enriched media, when the fed-batch production was inoculated at $3 \times 10^{6}$ cells/ $\mathrm{mL}$ with $\mathrm{B} 2$ enriched2 and F2 (Table 6). Thus, perfusion N-1 seed may not always be better than the batch seed with enriched media. Overall, it is apparent that there are strong interactions among different cell lines, target proteins, N-1 culture modes, production media and SDs (Table 6), for development of an intensified fed-batch cell culture process for mAb manufacturing. Even with a strong cell culture platform, a few optimization studies are still required to determine optimal growth and production conditions for each new mAb.

\section{Intensified Process $\mathrm{C}$ development for $\mathrm{mAb} 3$ production}

In order to develop a platform-intensified Process $C$ using perfusion $\mathrm{N}-1$ seed cultures, we performed cell culture studies using similar strategies for production of two more mAbs, i.e., mAb3 and mAb4. The comparison of cell culture performance between mAb3 Process $\mathrm{B}$ and $\mathrm{C}$ in large-scale bioreactors are shown in Fig. 4. Although mAb3 Process B was well developed before 1000-L runs (data not shown), the VCD profile including peak VCD for Process $C$ in 500-L bioreactors were almost doubled over Process B in 1000-L bioreactors (Fig. 4a). Although the cell viability for Process $C$ was slightly lower than Process $\mathrm{B}$ in the end of cell culture (Fig. 4b), titer for
Process $\mathrm{C}$ was doubled (Fig. 4c), while in-process quality attributes, e.g. charge variant species, $\mathrm{N}$ glycans and SEC impurities, were similar between Process $B$ and $C$ (Fig. 4d). The twofold increases in titer and volumetric productivity for Process $C$ were mainly attributed to the much higher VCD compared to Process B, while cell specific productivity was similar between Process $\mathrm{B}$ and Process $C$ (Table 4 and Fig. 4).

The changes from Process $\mathrm{B}$ to Process $\mathrm{C}$ for $\mathrm{mAb} 3$ are shown in Table 3. One of the major differences was $\mathrm{N}-1$ culture mode which changes from batch (Process $\mathrm{B}$ ) to perfusion (Process $\mathrm{C}$ ), resulting in much higher final VCD in the N-1 to enable much higher SD in the subsequent fed-batch production bioreactor (Table 3 and Fig. 4a). In addition, rebalanced B2 basal and F2 feed maintained higher VCD during the entire 14-day duration for Process $\mathrm{C}$ than Process $\mathrm{B}$, which significantly contributed to the titer improvement.

\section{Intensified Process $\mathrm{C}$ development for $\mathrm{mAb} 4$ production} The intensified Process $\mathrm{C}$ data for mAb4 production, including both 5-L and 500-L runs, were directly developed from Process A (Fig. 5). With previous Process $\mathrm{C}$ knowledge from other mAbs, mAb4 Process $\mathrm{C}$ was developed in just over 3 months. This shows one advantage of a strong platform in drastically reducing process development timelines. The intensified Process $\mathrm{C}$ was successfully scaled up from the 5 - $\mathrm{L}$ to $500-\mathrm{L}$ bioreactor scale (Fig. 5). Since only one fed-batch run at 500-L scale for mAb4 Process $\mathrm{C}$ is available, 5 - $\mathrm{L}$ run Process $C$ data with 4 replicates at the production bioreactor step is included to demonstrate the reproducibility (Fig. 5). The N-1 perfusion seed culture reached a final VCD of more than $100 \times 10^{6}$ cells $/ \mathrm{mL}$ for Process $C$, which was more than tenfold higher than the batch N-1 seed with a final VCD of about $8 \times 10^{6}$ cells/ $\mathrm{mL}$ for Process A (Fig. 5a). Similar to mAb1, the final viability for mAb4 Process $C$ was slightly lower than the batch seed (Fig. 5b). Due to the high SD at $16 \times 10^{6}$ cells $/ \mathrm{mL}$, the VCD profile for Process $C$ was significantly higher than Process A with a SD of only $1.5 \times 10^{6}$ cells $/ \mathrm{mL}$, while the $500-\mathrm{L}$ achieved a slightly 

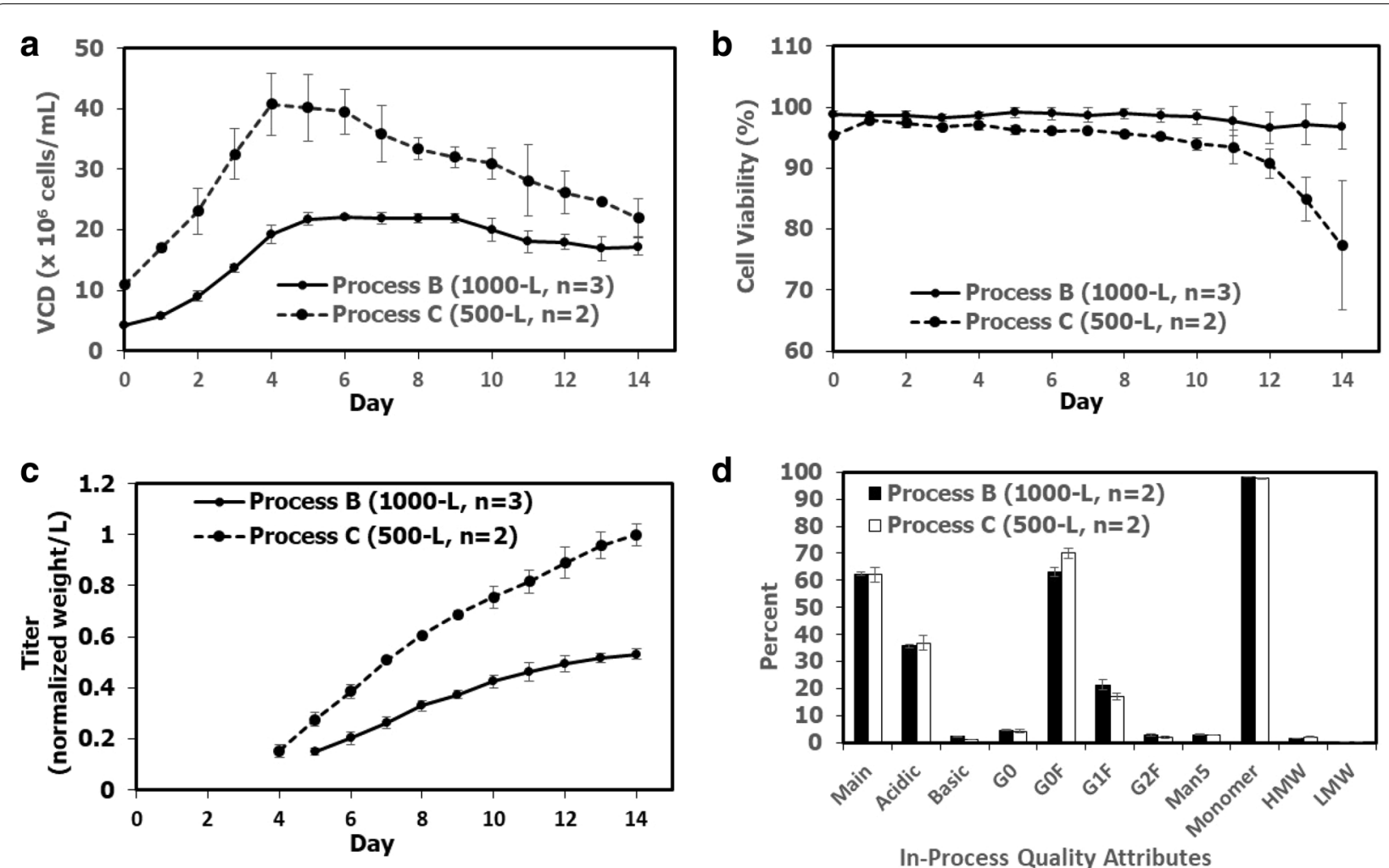

Fig. 4 a Viable cell density (VCD); b cell viability; c normalized titer, and $\mathbf{d}$ in-process quality attribute profiles on Day 14 at harvest for the subsequent fed-batch cell culture performance using Process B in 1000-L bioreactors and Process C in 500-L bioreactors for mAb3 production. The maximum titer on Day 14 for Process C at 500-L scale was normalized as 1 for mAb3. Most of the Process B values are reported as average \pm standard deviation $(n=3)$ except that quality attributes are reported as average \pm difference/2 $(n=2)$ because only two Day 14 samples were available for in-process quality assays, while Process $C$ values are reported as average \pm difference/2 $(n=2)$

higher VCD profile than 5-Ls for Process C (Fig. 5c). The cell viability profiles were similar for both Process $\mathrm{A}$ at $1000-\mathrm{L}$ and Process $\mathrm{C}$ at $500-\mathrm{L}$ for the entire duration, while lower cell viability was observed at 5 - $\mathrm{L}$ scale (Fig. 5d). Although the VCD increase for mAb4 Process $C$ was not as large as for $\mathrm{mAb} 2$ and $\mathrm{mAb} 3$, the titer was more than tripled from Process A to Process C (Fig. 5e), while quality attributes were comparable from Process A to Process C (Fig. 5f).

The changes from Process A to Process $\mathrm{C}$ for mAb4 are shown in Table 3 . In addition to the changes for $\mathrm{N}-1$ from batch to perfusion, higher SD at 10-20 $\times 10^{6}$ cells/mL and rebalanced B2 and F2, the basal was concentrated from B1 with $69 \mathrm{mM}$ total amino acids for Process A to the enriched B2 with $122 \mathrm{mM}$ total amino acids for Process $C$, while the feed was concentrated from $\mathrm{F} 1$ with $344 \mathrm{mM}$ total amino acids for Process A to the enriched F2 with $500 \mathrm{mM}$ total amino acids for Process C (Table 1).

\section{Discussion}

To the best of our knowledge, this is the first report to present relatively detailed data on fed-batch platform development which achieved very high titers for production of multiple mAbs within 10-14 days of bioreactor duration (Table 2) through fed-batch process intensification. Although titers are not disclosed in this report, they are comparable to the highest titers reported in the literature (Huang et al. 2010) for each of the 4 mAbs. Overall, limited literature is available for fed-batch process development with very high $(\sim 10 \mathrm{~g} / \mathrm{L})$ fed-batch titers. Since $10 \mathrm{~g} / \mathrm{L}$ titer on Day 18 for two proteins was reported for the first time (Huang et al. 2010), 9-10 g/L titers were reported for production of one $\mathrm{mAb}$ on Day 14 or Day 16 in two other case studies (Handlogten et al. 2018; Takagi et al. 2017). Conventional SDs of $\leq 1.5 \times 10^{6}$ cells $/ \mathrm{mL}$ were used in the above literature. In this study, however, the main strategies for the intensified fed-batch platform development were to increase the production 

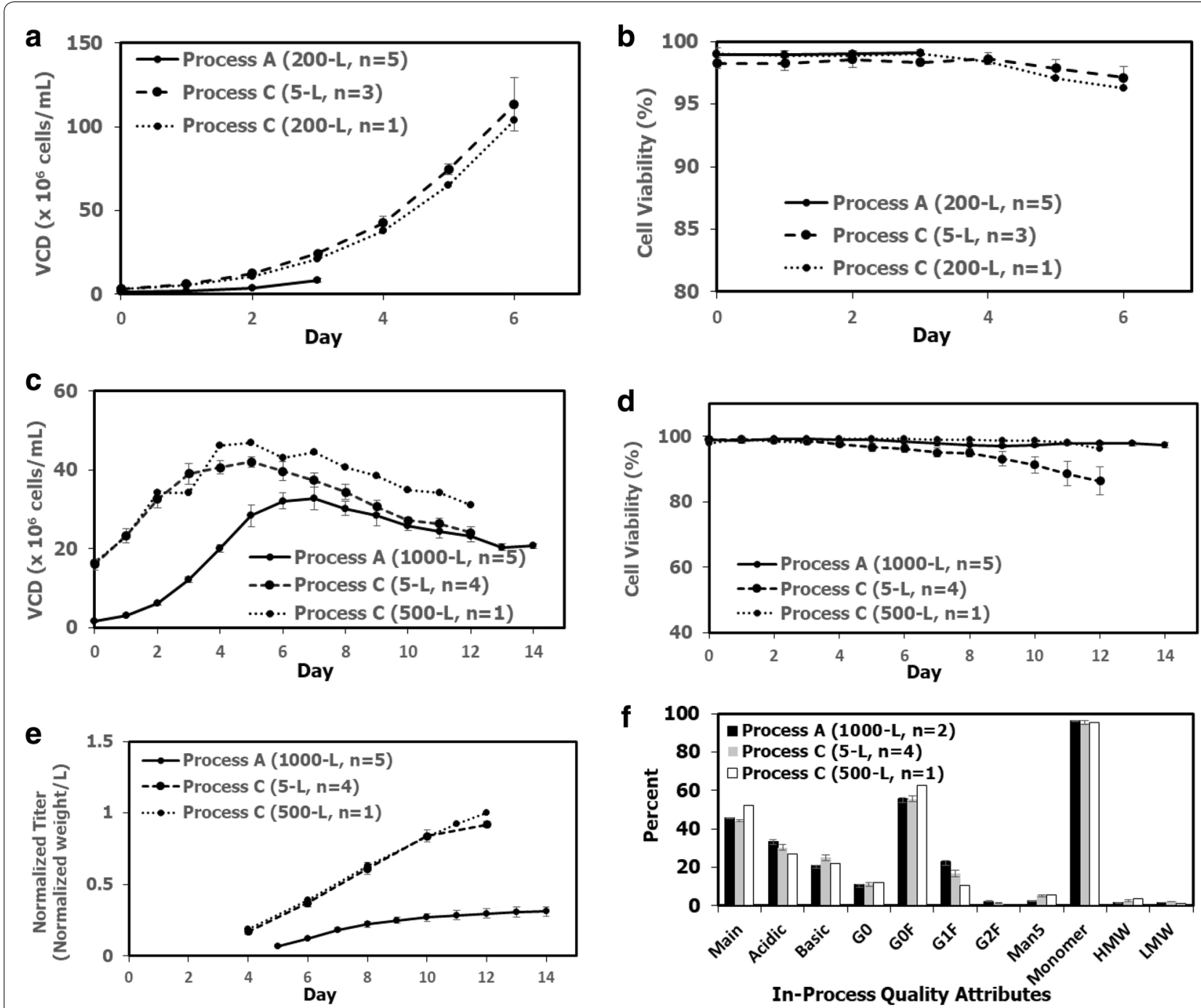

Fig. 5 a Viable cell density (VCD) and $\mathbf{b}$ cell viability profiles for the batch $N-1$ seed at 200-L scale $(n=5)$ for Process A, the perfusion N-1 seed at 5-L scale $(n=3)$, and the perfusion N-1 seed at 200-L scale $(n=1)$ for Process $C ; \mathbf{c} V C D, \mathbf{d}$ cell viability, e normalized titer profiles, and $\mathbf{f}$ in-process quality attribute profiles at harvest for the subsequent fed-batch cell culture performance using Process A in 1000-L bioreactors $(n=5)$, and Process $C$ in 5 - $\mathrm{L}$ bioreactors $(n=4)$ and 500-L bioreactor $(n=1)$ for mAb4 production. The maximum titer on Day 12 for Process $C$ at $500-L$ scale was normalized as 1 for mAb4. All Process C values at large scale are $n=1$, Process A quality attributes are reported as average \pm difference/2 ( $n=2$, because only two Day 14 in-process samples were available), and all other values are reported as average \pm standard deviation $(n=3-5)$

SD to $10-20 \times 10^{6}$ cells $/ \mathrm{mL}$ using $\mathrm{N}-1$ perfusion and to redesign basal and feed media for the high SD culture (Figs. 1, 3, 4, 5 and Tables 1, 2). Although only 4 mAbs were presented in this report, the intensified fed-batch platform has been successfully applied for production of additional $\mathrm{mAbs}$ with similar high titer range in our biologics pipeline (data not shown).

In addition to increasing titer and reducing manufacturing costs, reducing process development timelines is another goal for the biopharmaceutical industry. It is critical to develop $\mathrm{mAb}$ processes as quickly as possible to enable timely regulatory filings for early and late phase clinical trials and market approval due to the highly competitive nature in the biopharmaceutical industry. A strong platform process can significantly reduce the process development time and is important to gain process knowledge and for process-to-process consistency, which can facilitate process scale-up, streamline process transfer to manufacturing, benefit downstream process development, and enable consistent control of quality attributes (Bechmann et al. 2016; Li et al. 2010). In this study, it took approximately 6-9 months to develop intensified Process $\mathrm{C}$ strategies for $\mathrm{mAb} 1$ and $\mathrm{mAb} 3$, but it took approximately 3 months to achieve the same titer 
range in Process $\mathrm{C}$ for $\mathrm{mAb} 2$ and $\mathrm{mAb} 4$, demonstrating the advantages of a high-titer platform such as the one discussed in this report.

During development of the platform-intensified Process $\mathrm{C}$ strategies, there were interactions among many upstream factors, such as SD, nutrient strengths of basal and feed media, feeding strategies, temperature shifts, and $\mathrm{CHO}$ cell lines for expression of different mAbs (Fig. 2 and Table 6), even though all $\mathrm{CHO}$ cell lines in this study were created from the same platform parental CHO K1 GS cell line. This is in agreement with our previous report (Yongky et al. 2019). The mechanism of titer improvement for Process $\mathrm{C}$ was different for different $\mathrm{mAbs}$. For mAb2 and mAb3, the titer increase for Process $C$ was a result primarily of increased VCD, while for $\mathrm{mAb} 1$ and $\mathrm{mAb} 4$, the titer increase for Process $\mathrm{C}$ came from both increased VCD and increased cell specific productivity (Table 4 and Figs. 1, 3, 4, 5). Each mAb needed some individual changes to achieve higher titer than just a platform fit run. Those changes include medium enrichment and concentration, feed amounts and feed timing, and temperature shift conditions, which can be studied with several high-throughput runs using $50-\mathrm{mL}$ TubeSpin bioreactors and lab-scale bioreactors. The basal enrichment and concentration were important for mAb1 and $\mathrm{mAb} 4$, while the basal media for $\mathrm{mAb} 3$ was leaner to allow faster growth at the beginning but with enriched and concentrated feed in terms of total amino acids and osmolality to maintain high VCD for the rest of the culture duration (Table 2). For mAb2, both basal and feed with the highest nutrient strength produced the highest titer (Tables 2, 5 and Fig. 3). Nonetheless, Process $C$ platform media for production of all $\mathrm{mAbs}$ consist of the same base formulations of basal B2 and feed F2, which simplifies the intensified Process $\mathrm{C}$ development for different mAbs.

This intensified process has been run successfully for multiple cell lines in manufacturing, with comparable product quality attributes to earlier processes. In general, it is challenging to run replicates at large scale due to material cost and equipment demand. We had only two replicates for Process $\mathrm{C}$ quality attributes at $500-\mathrm{L}$ scale for mAb1 (Fig. 1f) and mAb3 (Fig. 4d), which might not be sufficient for effective statistical comparison. Because the reproducibility is not guaranteed to be high with only 2 replicates, we pooled $\mathrm{mAb} 1$ and $\mathrm{mAb} 3$ data to yield $>3$ replicates for the same processes in Fig. 6. Each value was normalized to the Process $C$ value before averaging to enable meaningful comparisons between mAbs. Although the final titer for Process $\mathrm{C}$ was doubled compared with Process $\mathrm{B}$, all in-process quality attributes, e.g. charge variant species, $\mathrm{N}$ glycan species and SEC impurity profiles were comparable (Fig. 6). Therefore, quality attributes were comparable regardless of the process used in this study.

One major potential limitation for large-scale manufacturing using an intensified fed-batch process was reported at $\mathrm{N}-1$ perfusion seed culture step with only $15.8 \times 10^{6}$ cells $/ \mathrm{mL}$ final VCD achieved using an inclined settler (Pohlscheidt et al. 2013). Overall though, there were not any major challenges during scale up of our N-1 perfusion cultures from 5-L with 1 ATF-2 to $200-\mathrm{L}$ and $500-\mathrm{L} \mathrm{N}-1$ bioreactors using 1 ATF- 6 device in this study. Assuming that we can scale up from a $500-\mathrm{L} \mathrm{N}-1$ perfusion process to a $2000-\mathrm{L} \mathrm{N}-1$ bioreactor containing 1700-L of culture volume using 2 ATF-10 devices, the amount of $\mathrm{N}-1$ perfusion culture at 2000-L scale is sufficient to inoculate a large production

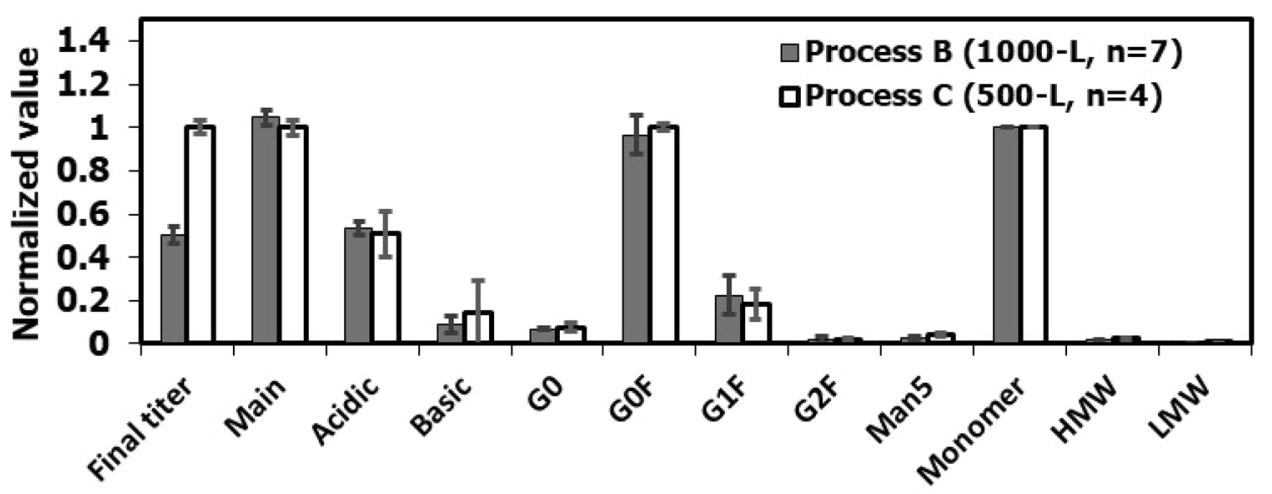

Titer and In-Process Quality Attributes

Fig. 6 Final titer and in-process quality attributes with combined data of mAb1 and mAb3 for Process B ( $n=7$ ) and Process $C$ ( $n=4$ ). In order to make statistical analysis more effective, average final titer, main peak, G0F, and monomer for Process C at 500-L scale was normalized as 1 for mAb1 and $\mathrm{mAb3}$, respectively 
bioreactor at 20,000-L scale with an initial volume of 10,000 to $14,000-\mathrm{L}$ at SD of $12-17 \times 10^{6}$ cells $/ \mathrm{mL}$. Thus, for high-demand biologics, it should be feasible to continue scaling the intensified Process $\mathrm{C}$ to a 20,000-L bioreactor while maintaining high titers in the production phase.

The intensified platform fed-batch Process $C$ developed in this study is very effective for mAb manufacturing. Since cell culture titer and production scale are two of the most important parameters to determine manufacturing costs (Kelley 2009; Mir-Artigues et al. 2019), Process $C$ with much higher titers (Table 2) and successful scale up in large-scale manufacturing makes the manufacturing costs lower than in the fed-batch Process A and Process $\mathrm{B}$. Effective $\mathrm{mAb}$ manufacturing with higher titer and volumetric productivity, better robustness and lower costs has been a goal for both academia and the biopharmaceutical industry for the last 3 decades. To achieve this goal, both fed-batch and perfusion modes have been intensively studied since the 1990s (Bielser et al. 2018; Kunert and Reinhart 2016; Li et al. 2010). Fed-batch culture, which has not fully matured yet with significant titer improvements continuously being reported, remains predominant in mAb manufacturing (Bielser et al. 2018; Kelley et al. 2018; Yongky et al. 2019). Although both fed-batch Process $\mathrm{C}$ and a perfusion production process achieve much higher volumetric productivities than a conventional fed-batch process, the strategy for intensified fed-batch Process $\mathrm{C}$ using N-1 perfusion with only a 6-day duration is simpler and more robust in operation than a perfusion production using a larger amount of media and a perfusion device at $\mathrm{N}$ production stage over the course of several weeks to months. The advances on the fed-batch intensified cell culture platform in this study further strengthen the advantage of fed-batch over perfusion production.

\section{Conclusion}

We have developed a novel platform strategy for cell culture fed-batch process intensification achieving the top titer range (comparable to the highest fed-batch titer reported in literature) for multiple mAbs using $10-20 \times 10^{6}$ cells/mL SD by perfusion N-1 seeds.

\section{Abbreviations}

ATF: Alternating tangential flow; $\mathrm{CHO}$ : Chinese hamster ovary; HMW: High molecular weight; LMW: Low molecular weight; mAb: Monoclonal antibody; SD: Seeding density; VCD: Viable cell density.

\section{Acknowledgements}

Thanks to our colleagues from Process Development Upstream, Downstream, Analytical, Scale-Up Lab, and Clinical Manufacturing Facility for supporting this study at Bristol-Myers Squibb.

\section{Authors' contributions}

JX designed lab work for $\mathrm{mAb} 1$ and $\mathrm{mAb2}$, analyzed data and wrote the manuscript. MSR designed and performed lab work for mAb4, analyzed data and polished the manuscript. MX designed and performed lab work for mAb1, analyzed data and reviewed the manuscript. SZ designed and performed lab work for mAb2, and analyzed data. $\mathrm{CH}$ designed and performed work for perfusion $\mathrm{N}-1$, and analyzed data. QH designed and performed lab work for mAb3, and analyzed data. MCB managed the team, analyzed data and reviewed the manuscript. ZL managed the team, analyzed data and reviewed the manuscript. All authors read and approved the final manuscript.

\section{Funding}

Not applicable.

Availability of data and materials

Not applicable.

Ethics approval and consent to participate

Not applicable.

\section{Consent for publication}

Not applicable.

\section{Competing interests}

No potential conflicts of interest were disclosed.

Received: 14 January 2020 Accepted: 16 March 2020

Published online: 23 March 2020

\section{References}

Bausch M, Schultheiss C, Sieck JB (2019) Recommendations for comparison of productivity between fed-batch and perfusion processes. Biotechnol J. https://doi.org/10.1002/biot.201700721

Bechmann J, Greulich B, Mueller MM, Schulz P, Wucherpfennig T, Bradl H (2016) Platform approach speeds process development. BioPharm Int 29(4):20-25

Bielser JM, Wolf M, Souquet J, Broly H, Morbidelli M (2018) Perfusion mammalian cell culture for recombinant protein manufacturing - a critical review. Biotechnol Adv 36(4):1328-1340. https://doi.org/10.1016/j.biote chadv.2018.04.011

Chen C, Wong HE, Goudar CT (2018) Upstream process intensification and continuous manufacturing. Curr Opin Chem Eng 22:191-198. https://doi. org/10.1016/j.coche.2018.10.006

Croughan MS, Konstantinov KB, Cooney C (2015) The future of industrial bioprocessing: batch or continuous? Biotechnol Bioeng 112(4):648-651. https://doi.org/10.1002/bit.25529

Du C, Xu J, Song H, Tao L, Lewandowski A, Ghose S, Borys M, Li Z (2019) Mechanisms of color formation in drug substance and mitigation strategies for the manufacture and storage of therapeutic proteins produced using mammalian cell culture. Process Biochem 86:127-135. https://doi. org/10.1016/j.procbio.2019.08.013

Ecker DM, Jones SD, Levine HL (2015) The therapeutic monoclonal antibody market. mAbs 7(1):9-14. https://doi.org/10.4161/19420862.2015.989042

Galbraith SC, Bhatia H, Liu H, Yoon S (2018) Media formulation optimization: current and future opportunities. Curr Opin Chem Eng 22:42-47. https:// doi.org/10.1016/j.coche.2018.08.004

Gallo-Ramírez LE, Nikolay A, Genzel Y, Reichl U (2015) Bioreactor concepts for cell culture-based viral vaccine production. Expert Rev Vaccines 14(9):1181-1195. https://doi.org/10.1586/14760584.2015.1067144

Handlogten MW, Lee-O'Brien A, Roy G, Levitskaya SV, Venkat R, Singh S, Ahuja S (2018) Intracellular response to process optimization and impact on productivity and product aggregates for a high-titer $\mathrm{CHO}$ cell process. Biotechnol Bioeng 115(1):126-138. https://doi.org/10.1002/bit.26460

Hay M, Thomas DW, Craighead JL, Economides C, Rosenthal J (2014) Clinical development success rates for investigational drugs. Nat Biotechnol 32(1):40-51. https://doi.org/10.1038/nbt.2786

Huang YM, Hu W, Rustandi E, Chang K, Yusuf-Makagiansar H, Ryll T (2010) Maximizing productivity of $\mathrm{CHO}$ cell-based fed-batch culture using chemically 
defined media conditions and typical manufacturing equipment. Biotechnol Prog 26(5):1400-1410. https://doi.org/10.1002/btpr.436

Jordan M, Mac Kinnon N, Monchois V, Stettler M, Broly H (2018) Intensification of large-scale cell culture processes. Curr Opin Chem Eng 22:253-257. https://doi.org/10.1016/j.coche.2018.11.008

Kaplon H, Reichert JM (2019) Antibodies to watch in 2019. mAbs 11(2):219238. https://doi.org/10.1080/19420862.2018.1556465

Kelley B (2009) Industrialization of mAb production technology: the bioprocessing industry at a crossroads. mAbs 1(5):440-449

Kelley B, Kiss R, Laird M (2018) A different perspective: how much innovation is really needed for monoclonal antibody production using mammalian cell technology? In: Advances in biochemical engineering/biotechnology. vol 165. Springer Science and Business Media Deutschland GmbH, pp 443-462

Kunert R, Reinhart D (2016) Advances in recombinant antibody manufacturing. Appl Microbiol Biotechnol 100(8):3451-3461. https://doi. org/10.1007/s00253-016-7388-9

Li F, Vijayasankaran N, Shen AY, Kiss R, Amanullah A (2010) Cell culture processes for monoclonal antibody production. mAbs 2(5):466-477. https:// doi.org/10.4161/mabs.2.5.12720

Lin PC, Chan KF, Kiess IA, Tan J, Shahreel W, Wong SY, Song Z (2019) Attenuated glutamine synthetase as a selection marker in $\mathrm{CHO}$ cells to efficiently isolate highly productive stable cells for the production of antibodies and other biologics. mAbs 11(5):965-976. https://doi.org/10.1080/19420 862.2019 .1612690

Lu RM, Hwang YC, Liu IJ, Lee CC, Tsai HZ, Li HJ, Wu HC (2020) Development of therapeutic antibodies for the treatment of diseases. J Biomed Sci. https ://doi.org/10.1186/s12929-019-0592-z

McHugh KP, Xu J, Aron KL, Borys MC, Li ZJ (2020) Effective temperature shift strategy development and scale confirmation for simultaneous optimization of protein productivity and quality in Chinese hamster ovary cells. Biotechnol Prog. https://doi.org/10.1002/btpr.2959 (In press)

Mir-Artigues P, Twyman RM, Alvarez D, Cerda Bennasser P, Balcells M, Christou P, Capell T (2019) A simplified techno-economic model for the molecular pharming of antibodies. Biotechnol Bioeng 116(10):2526-2539. https:// doi.org/10.1002/bit.27093

Moulijn JA, Stankiewicz A (2017) Process intensification. Encyclopedia of sustainable technologies. Elsevier, Amsterdam, pp 509-518

Padawer I, Ling WLW, Bai Y (2013) Case study: an accelerated 8-day monoclonal antibody production process based on high seeding densities. Biotechnol Prog 29(3):829-832. https://doi.org/10.1002/btpr.1719

Pohlscheidt M, Jacobs M, Wolf S, Thiele J, Jockwer A, Gabelsberger J, Jenzsch M, Tebbe H, Burg J (2013) Optimizing capacity utilization by large scale $3000 \mathrm{~L}$ perfusion in seed train bioreactors. Biotechnol Prog 29(1):222-229. https://doi.org/10.1002/btpr.1672

Rader RA, Langer ES (2015) 30 years of upstream productivity improvements. BioProcess Int 13(2). https://bioprocessintl.com/upstream-processing/ expression-platforms/30-years-upstream-productivity-improvements/
Stankiewicz Al, Moulijn JA (2000) Process intensification: transforming chemical engineering. Chem Eng Prog 96(1):22-33

Takagi Y, Kikuchi T, Wada R, Omasa T (2017) The enhancement of antibody concentration and achievement of high cell density $\mathrm{CHO}$ cell cultivation by adding nucleoside. Cytotechnology 69(3):511-521. https://doi. org/10.1007/s10616-017-0066-7

Tang P, Xu J, Louey A, Tan Z, Yongky A, Liang S, Li Z, Weng Y, Liu S (2020) Kinetic modeling of Chinese hamster ovary cell culture: factors and principles. Crit Rev Biotechnol 40(2):265-281. https://doi.org/10.1080/07388 551.2019 .1711015

Walsh G (2018) Biopharmaceutical benchmarks 2018. Nat Biotechnol 36(12):1136-1145. https://doi.org/10.1038/nbt.4305

Warikoo V, Godawat R, Brower K, Jain S, Cummings D, Simons E, Johnson T, Walther J, Yu M, Wright B, McLarty J, Karey KP, Hwang C, Zhou W, Riske F, Konstantinov K (2012) Integrated continuous production of recombinant therapeutic proteins. Biotechnol Bioeng 109(12):3018-3029. https://doi. org/10.1002/bit.24584

Wurm FM (2004) Production of recombinant protein therapeutics in cultivated mammalian cells. Nat Biotechnol 22(11):1393-1398. https://doi. org/10.1038/nbt1026

Wurm FM (2013) CHO Quasispecies_-implications for manufacturing processes. Processes 1:296-311

Xu J, Rehmann MS, Xu X, Huang C, Tian J, Qian NX, Li ZJ (2018) Improving titer while maintaining quality of final formulated drug substance via optimization of $\mathrm{CHO}$ cell culture conditions in low-iron chemically defined media. mAbs 10(3):488-499. https://doi.org/10.1080/19420 862.2018.1433978

Xu J, Tang P, Yongky A, Drew B, Borys MC, Liu S, Li ZJ (2019) Systematic development of temperature shift strategies for Chinese hamster ovary cells based on short duration cultures and kinetic modeling. mAbs 11(1):191-204. https://doi.org/10.1080/19420862.2018.1525262

Yang WC, Lu J, Kwiatkowski C, Yuan H, Kshirsagar R, Ryll T, Huang YM (2014) Perfusion seed cultures improve biopharmaceutical fed-batch production capacity and product quality. Biotechnol Prog 30(3):616-625. https:// doi.org/10.1002/btpr.1884

Yongky A, Xu J, Tian J, Oliveira C, Zhao J, McFarland K, Borys M, Li Z (2019) Process intensification in fed-batch production bioreactors using non-perfusion seed cultures. mAbs 11(8):1502-1514. https://doi.org/10.1080/19420 862.2019.1652075

Yoon SK, Kim SH, Lee GM (2003) Effect of low culture temperature on specific productivity and transcription level of anti-4-1BB antibody in recombinant Chinese hamster ovary cells. Biotechnol Prog 19(4):1383-1386. https ://doi.org/10.1021/bp034051m

\section{Publisher's Note}

Springer Nature remains neutral with regard to jurisdictional claims in published maps and institutional affiliations.

\section{Submit your manuscript to a SpringerOpen ${ }^{\circ}$ journal and benefit from:}

- Convenient online submission

- Rigorous peer review

- Open access: articles freely available online

- High visibility within the field

- Retaining the copyright to your article

Submit your next manuscript at $\boldsymbol{\nabla}$ springeropen.com 